\title{
Nurmen ongelmarikkakasvien syystorjunnalla nurmituotantoon lisää tehokkuutta
}

\author{
Raija Suomela \\ Maa- ja elintarviketalouden tutkimuskeskus, Kotieläintuotannon tutkimus, Tutkimusasemantie 15, \\ 92400 Ruukki, etunimi.sukunimi@mtt.fi
}

Nurmituotannon tehostaminen taloudellisesti kestävällä tavalla on nautakarjatiloilla ensisijaisen tärkeää. Haasteet rehun riittävän määrän ja laadun saavuttamiseksi lisääntyvät tiloilla, jotka pyrkivät laajentamaan tuotantoaan. Nurmen rikkakasvitorjunnalla on yleensä saavutettavissa edullisesti etuja rehun ruokinnallisen ja säilönnällisen laadun suhteen, mutta torjunnan hankaluus on aina ollut kevätkylvötöiden osuminen samaan ajankohtaan. Esimerkiksi voikukan torjunta-aika, eli nuppuaste on yleensä jo toukokuun alkupuolella. Viljelijällä on keväisin etusijalla kylvöjen onnistuminen ja aikaa muihin toimiin on vähän.

Keväällä tai kesällä tehdyn rikkakasvitorjunnan jälkeen korjattava rehusato sisältää väistämättä ne kuolleet rikkakasvit jotka on kasvustoon torjuttu: mitä enemmän rikkakasveja, sitä enemmän kuollutta kasviainesta torjunnan seurauksena. Nurmen rikkakasvien syystorjunnalla helpotettaisiin kevään työhuippua, mutta samalla pystyttäisiin varmistamaan, että kuollut kasvimassa ei siirry eläinten ruokintapöydälle. Syyskuinen torjunta onnistuessaan tuhoaa kaikki leveälehtiset rikkakasvit. Lisäksi syys-, talvi- ja kevätolosuhteet todennäköisesti pitävät huolen siitä, ettei kuollutta kasvimassaa ole toukokuulla havaittavissa kasvustossa.

Nurmen rikkakasvien syystorjuntakoe perustettiin MTT Ruukissa syksyllä 2009 yhteistyössä Berner Kasvinsuojelun kanssa Ely -keskusrahoitteisen Karjatilan kannattava peltoviljely (KARPE) hankkeen puitteissa. Koealueeksi valikoitui vanha ja erittäin voikukkavaltainen timoteinurmi, jossa laskennan perusteella voikukkia oli koesarjan alussa noin $40-50 \mathrm{kpl} / \mathrm{m}^{2}$. Rikkakasvien syystorjunnat suoritettiin vuosina 2009 ja 2010 syyskuun alkupuoliskolla. Torjunta-aineena käytettiin Starane XL tuotetta täydellä käyttömäärällä.

Syksyinen rikkakasvitorjunta tehosi täydellisesti. Lokakuussa kuollutta voikukkamassaa oli koealueella runsaasti. Seuraavana keväänä havaittiin, että kuollut aines oli talven aikana hävinnyt kokonaan, eikä yhtään elävää leveälehtistä rikkakasvia löytynyt torjutuilta ruuduilta. Koeruuduilta havainnoitiin kokeen alussa voikukan lisäksi myös piharatamoja, lemmikkiä, rönsyleinikkiä, ohdakkeita ja siankärsämöitä.

Kokonaissatotulosten oletettiin olevan huomattavasti pienempiä torjutuilla ruuduilla kuin torjumattomilla, sillä nurmi kävi erittäin harvaksi suuren voikukkamassan (20-30 \% tuoremassasta) hävittyä. Timotei pystyi kuitenkin ottamaan jo ensimmäisenä torjunnan jälkeisenä vuotena kasvutilaa itselleen, ja kokonaissatotulos oli koejäsenten välillä tasainen. Puhtaan timotein energiasato oli merkitsevästi suurempi torjutuilla ruuduilla.

Torjunnan jälkeinen täydennyskylvö on ehdoton edellytys kannattavalle nurmentuotannolle käytännön olosuhteissa, jos rikat ovat vallanneet pelloilla alaa nurmikasveilta runsaasti. Rikkakasvien torjunta syksyllä ja täydennyskylvö keväällä voisi olla erittäin toimiva nurmen ikää lisäävä kokonaisuus, kunhan se tehtäisiin täydennyskylvön kannalta riittävän aikaisessa vaiheessa.

Syystorjunnan tutkiminen on vielä kesken, mutta käytännössä menetelmä vaikuttaa erittäin lupaavalta. Vähintään sillä olisi mahdollista jaksottaa nurmen kasvinsuojelua ja täydennyskylvöä, ja tehostaa sitä kautta nurmen tuottokykyä.

Asiasanat: nurmen rikkakasvitorjunta, syystorjunta, voikukka, ongelmarikkakasvit, täydennyskylvö 


\section{Johdanto}

Nurmituotannon tehostaminen taloudellisesti kestävällä tavalla on nautakarjatiloilla ensisijaisen tärkeää. Haasteet rehun riittävän määrän ja laadun saavuttamiseksi lisääntyvät tiloilla, jotka pyrkivät laajentamaan tuotantoaan. Nurmen rikkakasvitorjunnalla on yleensä saavutettavissa edullisesti etuja rehun ruokinnallisen ja säilönnällisen laadun suhteen, mutta torjunnan hankaluus on aina ollut kevätkylvötöiden osuminen samaan ajankohtaan. Esimerkiksi voikukan torjunta-aika, eli nuppuaste on yleensä jo toukokuun alkupuolella. Viljelijällä on keväisin etusijalla kylvöjen onnistuminen ja aikaa muihin toimiin on vähän.

Syystorjunnalla on selkeitä etuja kevät- tai kesätorjuntaan verrattuna. Syyskuulla kiireisin sesonki on karjatiloilla takana ja on aikaa seurata nurmien kasvukuntoa. Optimaalisia ruiskutusoloja löytyy elo-syyskuussa yleensä pitkälle jaksolle ja peltojen kantavuuskin on syyskuussa yleensä vielä hyvä. Syyskuinen torjunta onnistuessaan tuhoaa kaikki leveälehtiset rikkakasvit, tärkeää on että kasvusto ei kuitenkaan ehdi liian reheväksi toisen tai kolmannen niiton jälkeen.

Torjunnan seurauksena rikkakasveista muodostuva kuollut kasvijäte näyttää hajoavan ja häviävän täysin talven aikana, eikä sitä joudu seuraavan kevät- tai kesäniiton myötä eläinten ruokintapöydälle. Keväällä tai kesällä tehdyn rikkakasvitorjunnan jälkeen korjattava rehusato sisältää sitä enemmän kuolleita rikkakasveja, mitä enemmän rikkakasveja kasvustossa on ollut. Puhdasta heinää sisältävän rehun säilöntä onnistuu todennäköisesti paremmin kuin epäpuhtauksia sisältävän rehun. Keväällä on mahdollisuus ruiskutuksen sijaan tehdä täydennyskylvö, ja nurmella on keväällä etulyöntiasema kasvuun lähdössä rikkakasveihin verrattuna.

\section{Aineisto ja menetelmät}

Nurmen rikkakasvien syystorjuntakoe perustettiin MTT Ruukissa syksyllä 2009 yhteistyössä Berner Kasvinsuojelun kanssa Ely -keskusrahoitteisen Karjatilan kannattava peltoviljely (KARPE) hankkeen puitteissa. Koealueeksi valikoitui vanha ja erittäin voikukkavaltainen timoteinurmi, jossa laskennan perusteella voikukkia oli koesarjan alussa noin $40-50 \mathrm{kpl} / \mathrm{m}^{2}$. Rikkakasvien syystorjunnat suoritettiin vuosina 2009 ja 2010 syyskuun alkupuoliskolla (taulukko 1). Torjunta-aineena käytettiin Starane XL -tuotetta täydellä käyttömäärällä.

Taulukko 1. Nurmen rikkakasvitorjuntojen toteuttaminen MTT Ruukissa vuosina 2009 ja 2010

\begin{tabular}{lllll}
\hline Vuosi & Torjunta pvm & $\begin{array}{l}\text { Starane XL } \\
\text { käyttömäärä }\end{array}$ & $\begin{array}{l}\text { Vuorokauden } \\
\text { keskilämpötila }\end{array}$ & $\begin{array}{l}\text { Kasvukauden } \\
\text { päättyminen }\end{array}$ \\
\hline 2009 & 11.9 .2009 & $1,81 /$ ha & $9,8{ }^{\circ} \mathrm{C}$ & 27.9 .2009 \\
2010 & 10.9 .2010 & $1,81 /$ ha & $12,7{ }^{\circ} \mathrm{C}$ & 10.10 .2010 \\
\hline
\end{tabular}

\section{Torjunnan vaikutus timotein satoon}

Syksyinen rikkakasvitorjunta tehosi täydellisesti. Lokakuussa 2009 kuollutta rikkakasvimassaa oli koealueella runsaasti. Koeruuduilta oli havainnoitu voikukan lisäksi myös satunnaisesti piharatamoja, lemmikkiä, rönsyleinikkiä, ohdakkeita ja siankärsämöitä. Torjuntaa seuraavana keväänä 2010 havaittiin, että kuollut aines oli talven aikana hävinnyt kokonaan, eikä yhtään elävää leveälehtistä rikkakasvia löytynyt torjutuilta ruuduilta.

Kokonaissatotulosten oletettiin olevan huomattavasti pienempiä torjutuilla ruuduilla kuin torjumattomilla, sillä nurmi kävi erittäin harvaksi suuren voikukkamassan (20-30 \% tuoremassasta) hävittyä. Timotei pystyi kuitenkin ottamaan jo ensimmäisenä torjunnan jälkeisenä vuotena kasvutilaa itselleen, ja kokonaissatotulokset (taulukko 2, kuva 1) olivat koejäsenten välillä tasaiset. Puhtaan timotein kokonaissatosatotulokset olivat merkitsevästi suuremmat torjutuilla ruuduilla.

Taulukko 2. Syystorjuntakokeen kuiva-ainesadot sekä timotein kuiva-ainesadot niitoittain sekä kokonaiskuivaainesadot (kg ka /ha) vuonna 2010

\begin{tabular}{lcccccc}
\hline & \multicolumn{3}{c}{ Kuiva-ainesadot, kg ka/ha } & \multicolumn{3}{c}{ Timotein kuiva-ainesadot, kg ka/ha } \\
Koejäsen & 1. Niitto & 2. Niitto & Kokonaissato & 1. Niitto & 2. Niitto & Kokonaissato \\
\hline Ei torjuntaa & 5866 & 3206 & 9072 & 4582 & 2380 & 6962 \\
Torjunta & 5258 & 3781 & 9031 & 5142 & 3503 & 8645 \\
\hline Merkitsevyys* & $* * *$ & $* *$ & & $*$ & $* * *$ & $* * *$ \\
\hline
\end{tabular}



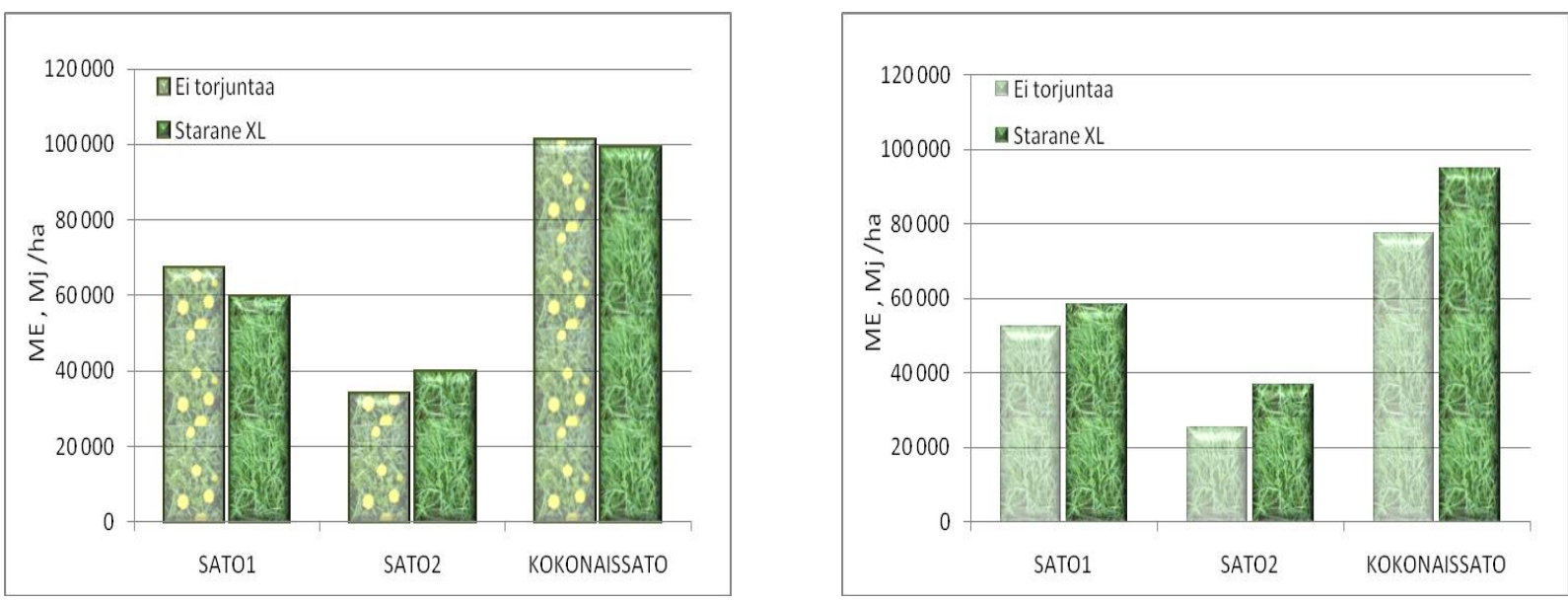

Kuva 1. Rikkakasvitorjunta voikukkavaltaisella nurmella ei vähentänyt saatavaa energiasatoa vuonna 2010. Timotein sato kasvoi ilmeisesti lisääntyneen kasvutilan ja ravinteiden saannin avulla rikkakasvitorjunnan saaneilla nurmiruuduilla.

Koetta jatkettiin kasvukausilla 2010 ja 2011, mutta alun perin täydellisesti onnistuneen torjunnan jälkeen ei kasvustossa havaittu kuin että nurmen ikä (kesä 2011 oli 5. nurmivuosi) ja torjunnan tuottama aukkoisuus kasvustossa lisäsivät juolavehnän mahdollisuutta runsastua rikkakasvitorjunnan saaneissa kasvustoissa. Toisaalta voikukkia iti sekä kesällä 2010 että 2011 torjuntaruuduilla, koska vierellä olevista ruuduista joilla rikkakasvitorjuntaa ei ollut tehty, levisi erittäin paljon voikukan siemeniä ympäristöön. Vuoden 2010 torjuntasaavutus olikin siemenlevintäisten voikukkien häviäminen kasvustosta syksyn ja talven 2010-2011 aikana.

Sadon laatutulokset eivät ole valmistuneet vielä. Oletettavaa on, että runsaasti voikukkia sisältävän nurmirehun kaliumpitoisuudet ovat suuremmat kuin puhtaan timoteinurmen. Runsas kaliumpitoisuus rehussa voi aiheuttaa nautakarjassa poikima- ja laidunhalvauksia.

\section{Täydennyskylvöllä tiheä kasvusto}

Torjunnan jälkeinen täydennyskylvö on ehdoton edellytys kannattavalle nurmentuotannolle käytännön olosuhteissa, jos rikat ovat vallanneet pelloilla alaa nurmikasveilta runsaasti. Näin käy helposti jos nurmen perustaminen epäonnistuu vähänkään. Tähän kokeeseen täydennyskylvön sovittaminen ei koeteknisistä syistä ikävä kyllä onnistunut. Rikkakasvien torjunta syksyllä ja täydennyskylvö keväällä voisi olla erittäin toimiva nurmen ikää lisäävä kokonaisuus, kunhan se tehtäisiin täydennyskylvön kannalta riittävän aikaisessa vaiheessa.

Syystorjunnan tutkiminen on vielä kesken, mutta käytännössä menetelmä vaikuttaa erittäin lupaavalta. Vähintään sillä olisi mahdollista jaksottaa nurmen kasvinsuojelua ja täydennyskylvöä, ja tehostaa sitä kautta nurmen tuottokykyä. 